\title{
Quality of a life skills training program in Karnataka, India - a quasi experimental study
}

\author{
Banandur S. Pradeep 1, Banavaram Anniappan Arvind ${ }^{1 *}$ D, Srinivas Ramaiah², Swati Shahane ${ }^{1}$, Lavanya Garady ${ }^{1}$ \\ Mutharaju Arelingaiah', Gopalkrishna Gururaj ${ }^{1}$ and Gananatha Shetty Yekkaru ${ }^{3}$
}

\begin{abstract}
Background: Youth focused Life Skills Education and Counseling Services (YLSECS) program, trained teachers/ National Service Scheme (NSS) officers to deliver Life Skills Education (LSE) and counseling services to college going youth in the state of Karnataka in India. Available evaluation of life-skills training program have neglected the recording and or reporting of outcome among those trained to implement life-skills training program. Present paper highlights the quality of YLSECS training program and change in perception among teachers/NSS-officers trained in-terms of improvement in their cognitive/affective domains.
\end{abstract}

Methods: YLSECS program focused on World Health Organization identified ten essential domains of life-skills. Participants of the YLSECS program were trained by adopting facilitatory approach based on the principles of Kolb's learning theory. Quasi experimental study design was used to evaluate the outcome of training among participants. Quality of the training was assessed using scoring system and change in perception was assessed using Likert scale. Statistical significance of change in perception before and after training was assessed by paired't' test for proportion.

Results: Overall, 792 participants rated the quality of training as either "good" or "excellent". Post-training, significant $(p<0.001)$ proportion of the participants reported improved awareness about life-skills (before training 49.9 to $74.4 \%$ vs post-training range from 91.6 to $95.1 \%$ for various domains). There was statistically significant $(p<0.001)$ increase in participants reporting "very confident" in teaching various life skill domains (before training from 22.7 to $34.2 \%$ for various domains and post-training it ranged from 65.2 to $74.7 \%$ for various domains). There was modest increase in participants reporting perceived ability to conduct life-skills workshop "without assistance" post-training (before training from 16.8 to $22.9 \%$ for various domains vs post-training ranged from 29.8 to $36.8 \%$ for various domains). Interestingly, considerable proportion of participants who prior to training reported being confident in providing life skills training (without any assistance), later (i.e post training) reported they need some/more assistance for the same.

Conclusion: YLSECS training program significantly improved participants knowledge and confidence in imparting lifeskills and highlight the need for continued handholding of participants for effective implementation of LSE and counseling service program.

Keywords: Teachers, Life skills education, Training, Quality, India

\footnotetext{
* Correspondence: aravind_baa@yahoo.co.in

1 Department of Epidemiology, National Institute of Mental Health and

Neurosciences, Bengaluru 560029, India

Full list of author information is available at the end of the article
}

(c) The Author(s). 2019 Open Access This article is distributed under the terms of the Creative Commons Attribution 4.0 International License (http://creativecommons.org/licenses/by/4.0/), which permits unrestricted use, distribution, and reproduction in any medium, provided you give appropriate credit to the original author(s) and the source, provide a link to the Creative Commons license, and indicate if changes were made. The Creative Commons Public Domain Dedication waiver (http://creativecommons.org/publicdomain/zero/1.0/) applies to the data made available in this article, unless otherwise stated. 


\section{Background}

The demographic-socioeconomic-political development of a nation is dependent on its youth population. "Youth bulge", in India presents an opportunity to harness the demographic dividend [1]. To maximize the benefits of this demographic dividend, youth need to be healthy, educated and skilled [2]. But conversely significant proportion of youth in India is affected with several health problems including poor mental health [3-5]. Therefore, empowering youth with quality education and twenty-first century skills like creative thinking, decision making, communication etc. would help them to remain healthy and gain employment $[3,6]$, thereby enable youth to contribute productively to the society. Unfortunately, the current system of education in the country is restricted in its ability to provide youth with these necessary skills [7] with a similar situation in Karnataka (state in southwestern region of India).

Globally preparing youth to thrive in the future knowledge economy, in the light of advancements in technologies and industries, is considered a major challenge for the twenty-first century [8]. Life Skills Based Education is known to play a crucial role in youth health promotion, education and overall development [9] by enabling them to adopt healthy personal behaviors, improving educational outcomes and earning potential [10, 11]. Considering the need, National Service Scheme wing, Department of Youth Empowerment and Sports, Government of Karnataka supported by Department of Epidemiology, Centre for Public Health, National Institute of Mental Health and Neuro Science (NIMHANS), initiated the "Youth focused Life Skills Education and Counseling Services (YLSECS) program" for promoting mental health and well being of youth in the state.

The National Service Scheme (NSS) is a Scheme of Government of India, Ministry of Youth Affairs \& Sports, which aims at providing an opportunity to the student youth of India to take part in various government led community service activities and programs [12]. YLSECS program, therefore, focused on training NSS coordinators/officers and teaching faculty from the departments of pre-university education, collegiate education, technical education and medical education. Training was aimed at enhancing and strengthening the knowledge and capacity of NSS coordinators/officers and teachers to impart life skills training to youth in their respective institutions. Review of life skills education programme implemented across the globe, has observed that existing training under such programme does not adequately address and report the psychosocial skills and attitudes of teachers (who are expected to train students) trained [10] The Present paper addresses this information gap by reporting the quality, of YLSECS training program and post training improvement in knowledge and confidence among participants (including NSS coordinators/officers and teachers) to impart life skills training.

\section{Methods}

Between January and July 2017, 28 life skills training workshops were conducted under YLSECS program. These trainings were conducted in a class room setting in the department of Epidemiology at NIMHANS, Bangalore. Participants (NSS officers/coordinators and teachers) for the training were deputed by the government agencies. The entire training program was conceptualized around adult learning principles emphasizing active participatory teaching-learning methods. Ten different domains of Life skills as identified by World Health Organization [13] and expert consultation namely: self-awareness, empathy, coping with stress, coping with emotions, interpersonal skills, critical thinking, decision making, problem solving, communication skills and creative thinking were selected for training under the YLSECS program. The training program served the dual purpose of equipping participants with relevant life skills knowledge and also to demonstrate how to conduct such trainings in their respective settings through facilitatory approach.

\section{YLSECS training process}

Overall, each training workshop was planned for 5 days and each day 2 domains were covered involving $3-4 \mathrm{~h}$ per domain. In each workshop 25 to 30 participants were enrolled and they were trained by master facilitators. Facilitators were specialist in the field of psychology and social sciences and were skilled in conducting the training utilizing facilitatory approach.

The process of training participants in YLSECS program was grounded in Kolb's learning theory which emphasizes learning as the process whereby knowledge is created through the transformation of experience [14]. Accordingly, the process of facilitation in a particular domain of life skills involved sequential steps namely activities, reflective observation, abstract conceptualization and summarizing. Firstly, trainees participated in an activity which was designed to expose the participants or make them experience a situation that needs them to use a particular life skills domain. Subsequently, participants were asked to reflect on their perception, experience and opinion about the activity (Reflective Observation). This was followed by Abstract Conceptualization, wherein facilitator conceptualized the activity performed underpinning the role of a particular Life Skill domain. This enhances participants understanding and knowledge about that particular life skill domain. Towards the end, each session was concluded by summarizing the learnings together with suggestions for the trainers on how to effectively 
implement the activity/training in their respective institutions.

Predesigned semi structured self administered feedback evaluation questionnaire was developed to collect information on sociodemographic characteristics of the participants, their feedback on quality of each session of training and the outcome of YLSECS training program. Effect of the training in improving participant's awareness about life skills, increasing their level of confidence in teaching life skills and perceived ability to independently conduct life skills training workshop was assessed through a quasi experimental study -the one group pretest posttest study design. Information was collected from the participants immediately before and after the training program through trained data collectors.

Quality of the training was assessed considering the content, communication, presentation skills and teaching methodology adopted by the facilitator. For each of the component participants scored on a 5-point scale: Poor (score - 0), Average (score - 1), Good (score - 2), Very good (score - 3) and Excellent (score - 4). The total score for each domain was calculated by summing the scores of all components. Thus, for each component the score ranged between 0 and 4 and for each life skill domain the score ranged between 0 and 16. Based on the total score, quality of the training was graded as follows: poor (Scores - 0 to 4), fair (score- 5 to 9 ), good (score- 10 to 13) and excellent (score- 14 to 16).

Effect of training program in improving knowledge and perception was assessed by considering the following variables among participants viz. awareness regarding life skills, level of confidence in teaching life skills and level of perceived ability to independently conduct life skills training program. Awareness about life skills was assessed through questions that elicited binary response (Yes or No) for various domains of life skills. Participants 'Level of Confidence' in teaching Life skills and 'Perceived Ability' to independently conduct the Life skills training program was assessed using likert scale. "Level of confidence" was graded as not confident, somewhat confident and very confident and "perceived ability" was graded as without assistance, with little assistance and with more assistance. Each participant was given a unique training ID number to pair his/her given information before and after the training program.

The difference in the responses regarding awareness of life skills, level of confidence to teach life skills and perceived level of assistance needed for independently conducting Life Skills training program before and after the training was assessed by paired " $\mathrm{t}$ " test for proportion. All analysis was undertaken using SPSS version 22.0 and $p$-value $<0.05$ was considered statistically significant.

\section{Results}

Over a period of 7 months, 792 participants were trained under YLSECS program. Mean age of the participants was 40.1 years and males constituted $78 \%$. Majority of the participants had completed diploma/degree/ postgraduate studies (98\%) and were employed either as lecturer $(42.7 \%)$ or as assistant professor $(32.3 \%)$ in their respective institutions (Table 1).

Overall, the quality of training for various domains of YLSECS training program was rated as either "Good" or "Excellent". The quality of training for effective communication (mean score $=14.02)$ and critical thinking/decision making (mean score $=14.03$ ) was rated as excellent. The content, communication, presentation and teaching methodology for all the domains was rated as "Very Good (score-3)" or "Excellent (score-4)" (Fig. 1).

There was statistically significant $(p<0.001)$ improvement in awareness about different domains of life skills after training. Before training, awareness about different domains of life skill varied between $49.9 \%$ (for coping with emotions) to $74.4 \%$ (for communication skills). After training, for each domain, more than $90 \%$ of the

Table 1 Socio demographic characteristics of participants of YLSECS training program

\begin{tabular}{ll}
\hline Socio demographic characteristics $(n=792)$ & $\mathrm{N}(\%)$ \\
\hline Age Mean (SD) & $40.1(9.7)$ \\
Gender & $615(78.0)$ \\
Male & $177(22.0)$ \\
Female & \\
Place of residence & $443(56.0)$ \\
Urban & $349(44.0)$ \\
Rural & \\
Education (highest standard studied) & $3(0.4)$ \\
High school & $13(1.6)$ \\
Pre-University (Class 11 and 12) & $152(19.2)$ \\
Degree/Diploma & $624(78.8)$ \\
Post-graduation and above & \\
Current position & $338(42.7)$ \\
Lecturer & $256(32.3)$ \\
Assistant Professor & $37(4.7)$ \\
Others & $161(20.3)$ \\
YPs & \\
Religion & $623(78.1)$ \\
Hindu & $153(19.3)$ \\
Others & $16(2.0)$ \\
Marital status & $63(8.0)$ \\
Currently married & \\
Never Married & \\
Others & \\
\hline
\end{tabular}




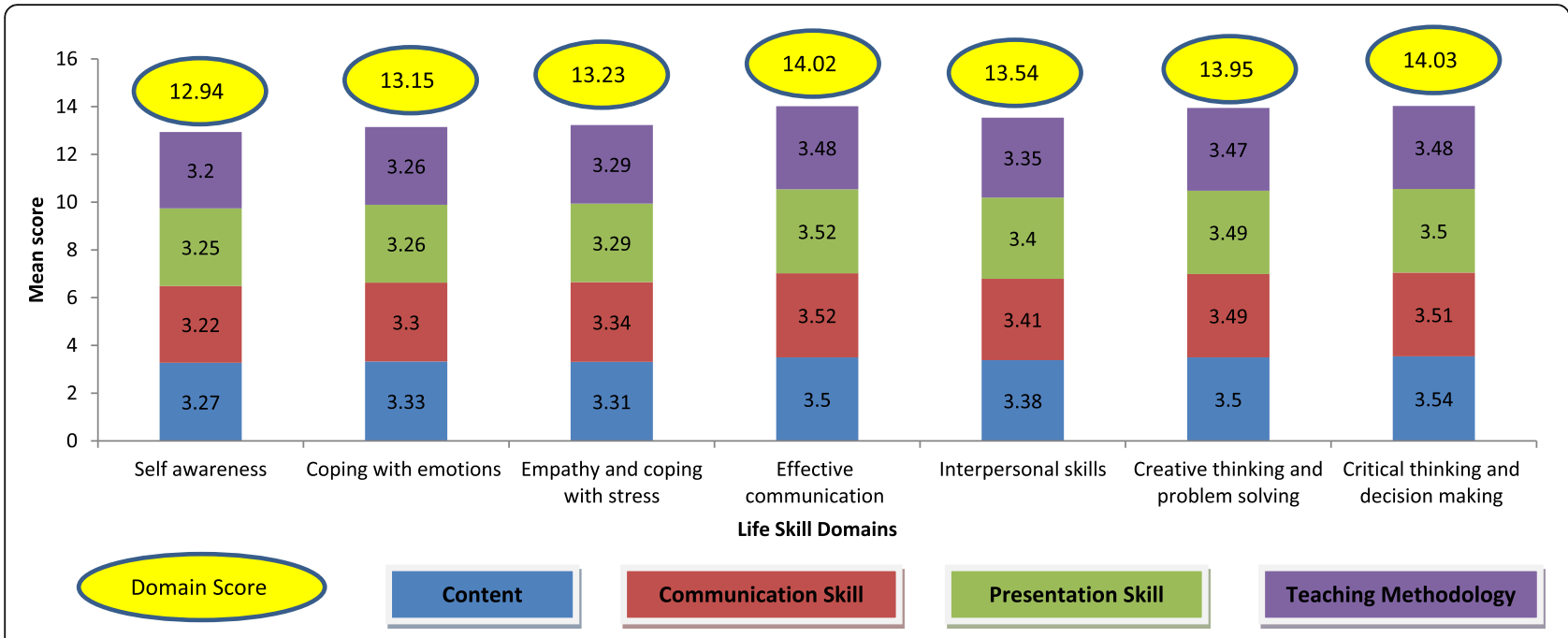

Fig. 1 Feedback of participants on domain and component wise quality of YLSECS training program. For each domain (i.e self-awareness, coping with emotion etc), score ranges between 0 and 16; For each component within a given domain (i.e content, communication skill, presentation skill, teaching methodology), score ranges between 0 and 4

participants reported improved awareness. The percentage increase in awareness was relatively more in the domains of coping with emotions $(41.7 \%)$, critical thinking (41.7\%) and coping with stress (37.0\%) (Fig. 2).

The proportion of participants in "very confident" category under various domains of life skills before training ranged from $22.7 \%$ for coping with emotion to $34.3 \%$ for communication skills and after training it varied from $65.2 \%$ for coping with stress to $74.7 \%$ for communication skills (i.e more than doubled across all domains of life skills). This difference in proportion was statistically significant $(p<0.05)$ (Table 2). Similarly, there was statistically significant $(\mathrm{p}<0.05)$ increase in proportion of participants reporting ability to conduct life skills workshop without any assistance after training (ranged from 29.8\% for critical thinking to $36.8 \%$ for communication skills) (Table 3). Overall, after training, the number of participants who felt they could impart life skills training without any assistance increased by one and half to two times across all the domains.

Among those participants who reported to be not confident of conducting a life skills training program before training, nearly $90 \%$ of the participants shifted to either somewhat confident or very confident category after training (range $-91.6 \%$ for self awareness to $96.7 \%$ for problem solving). Similarly, among those participants who belonged to somewhat confident category before training, more than $2 / 3 \mathrm{rd}$ of them (range $-57.4 \%$ for coping with emotions to $70.8 \%$ for communication skills) moved to very confident category after training.

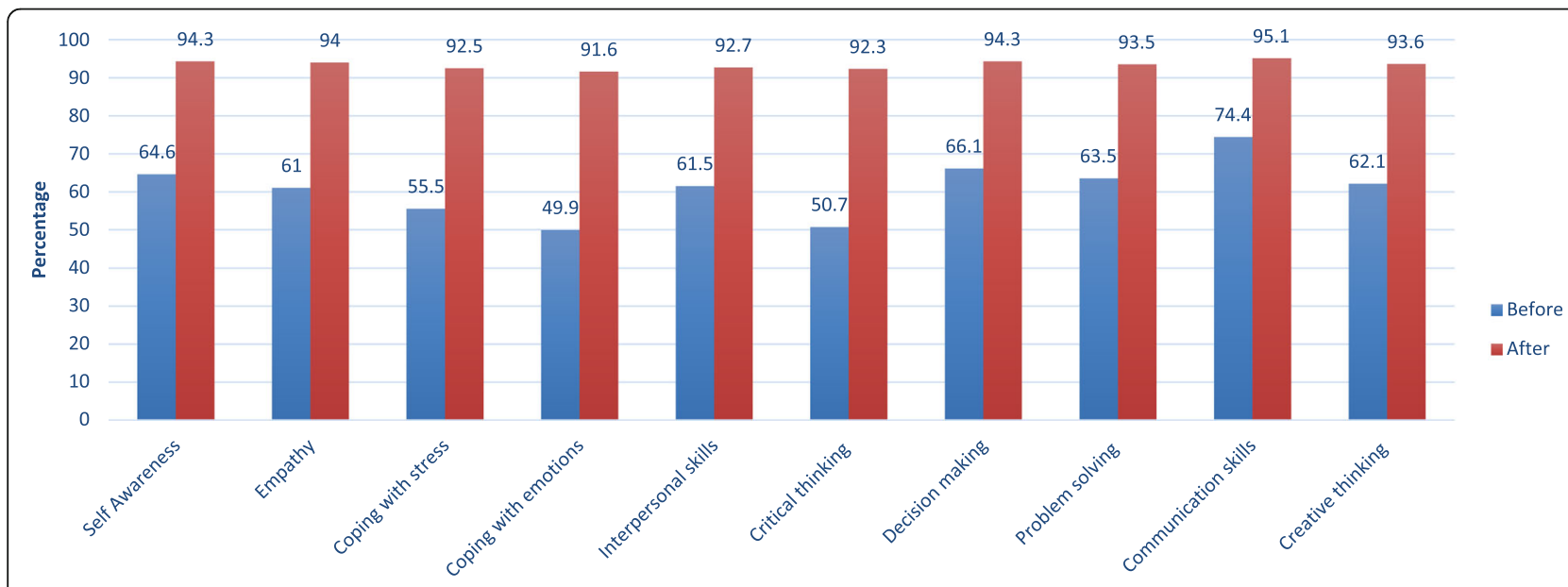

Life Skill Domains

Fig. 2 Percentage of participants who were aware about 10 domains of Life Skill before and after training 
Table 2 Perceived level of confidence in teaching Life Skills among participants before and after training

\begin{tabular}{|c|c|c|c|c|c|c|c|c|}
\hline \multirow[t]{2}{*}{ SI no } & \multirow[t]{2}{*}{ Life skills } & \multicolumn{3}{|l|}{ Before training } & \multicolumn{3}{|l|}{ After training } & \multirow[t]{2}{*}{ ' $p$ ' value } \\
\hline & & $\begin{array}{l}\text { Not confident } \\
\mathrm{n}(\%)\end{array}$ & $\begin{array}{l}\text { Somewhat confident } \\
\mathrm{n}(\%)\end{array}$ & $\begin{array}{l}\text { Very confident } \\
\mathrm{n}(\%)\end{array}$ & $\begin{array}{l}\text { Not confident } \\
\mathrm{n}(\%)\end{array}$ & $\begin{array}{l}\text { Somewhat confident } \\
\mathrm{n}(\%)\end{array}$ & $\begin{array}{l}\text { Very confident } \\
\mathrm{n}(\%)\end{array}$ & \\
\hline 1 & Self-awareness & $141(18.2)$ & $437(56.5)$ & $196(25.3)$ & $15(1.9)$ & $217(28.1)$ & $539(69.9)$ & $<0.0001$ \\
\hline 2 & Empathy & $182(22.7)$ & $386(50.3)$ & 199(25.9) & $21(2.7)$ & $217(28.2)$ & $532(69.1)$ & $<0.0001$ \\
\hline 3 & Coping with stress & $206(26.7)$ & $379(49.2)$ & 186(24.1) & $29(3.8)$ & 238(31.0) & $500(65.2)$ & $<0.0001$ \\
\hline 4 & Coping with emotions & $210(27.7)$ & $375(49.5)$ & $172(22.7)$ & $28(3.6)$ & 236(30.7) & $504(65.6)$ & $<0.0001$ \\
\hline 5 & Interpersonal skills & $178(23.5)$ & $387(51.1)$ & 193(25.5) & $15(2.0)$ & 236(30.7) & $517(67.3)$ & $<0.0001$ \\
\hline 6 & Critical thinking & $220(29.3)$ & $348(46.4)$ & 182(24.3) & $22(2.9)$ & 239(31.3) & $503(65.8)$ & $<0.0001$ \\
\hline 7 & Decision making & 148(19.4) & $394(51.7)$ & $220(28.9)$ & $17(2.2)$ & 208(27.0) & $544(70.7)$ & $<0.0001$ \\
\hline 8 & Problem solving & 164(21.9) & $350(46.7)$ & $236(31.5)$ & $16(2.1)$ & $201(26.3)$ & $548(71.6)$ & $<0.0001$ \\
\hline 9 & Communication skills & $125(16.4)$ & $376(49.3)$ & $261(34.3)$ & $18(2.3)$ & $176(22.9)$ & $574(74.7)$ & $<0.0001$ \\
\hline 10 & Creative thinking & 188(23.9) & $366(46.6)$ & $212(27.0)$ & $17(2.2)$ & 227(29.7) & $520(68.1)$ & $<0.0001$ \\
\hline
\end{tabular}

Majority (ranging from $82.3 \%$ for critical thinking to $89.5 \%$ for communication skills) of the participants who expressed they were very confident before the training program remained very confident after the training program (Table 4).

In terms of the perceived ability to conduct the life skills training program with or without assistance (Table 5), among the participants who had thought they would need more assistance before the training program, majority of the participants reported improved ability after training. Nearly $2 / 3$ rd to $3 / 4$ th of the participants opined they would need less or no assistance to conduct the life skills training program after undergoing the training (Range $-67.2 \%$ for communication skills to 80.2\% for Empathy). Among the participants who expressed the need for less assistance before training, nearly $1 / 3$ rd of the participants reported they do not need assistance after the training (Range - 29.4\% for creative thinking to $38.1 \%$ for self-awareness and Communication skills) and nearly $1 / 5$ th of them reported that they need more assistance after-training (range $17.8 \%$ for creative thinking to $20.4 \%$ for critical thinking).Among those who reported that they do not require any assistance prior to training, nearly $50 \%$ reported that they either need little or more assistance after the training (range $-40.5 \%$ for communication skills to $54.8 \%$ for coping with stress).

\section{Discussion}

YLSECS training program is perhaps the largest training program, in the state of Karnataka, aimed at empowering NSS officers and other teaching faculty with requisite knowledge and skills for imparting life skills to college going youth. The National Service Scheme (NSS) implemented in educational institutions of the state, through NSS officers, work towards developing the personality and character of the student youth through voluntary community service [7]. In this context, training of NSS officers and teachers who can reach considerable segment of youth population was deemed appropriate

Table 3 Perceived level of assistance needed in conducting Life Skills workshops among participants before and after training

\begin{tabular}{|c|c|c|c|c|c|c|c|c|}
\hline \multirow[t]{2}{*}{ SI no } & \multirow[t]{2}{*}{ Life skills } & \multicolumn{3}{|l|}{ Before training } & \multicolumn{3}{|l|}{ After training } & \multirow[t]{2}{*}{$p$ value } \\
\hline & & $\begin{array}{l}\text { With little } \\
\text { assistance } n(\%)\end{array}$ & $\begin{array}{l}\text { With more } \\
\text { assistance } \mathrm{n}(\%)\end{array}$ & $\begin{array}{l}\text { Without } \\
\text { assistance n (\%) }\end{array}$ & $\begin{array}{l}\text { With little } \\
\text { assistance } \mathrm{n}(\%)\end{array}$ & $\begin{array}{l}\text { With more } \\
\text { assistance n (\%) }\end{array}$ & $\begin{array}{l}\text { Without } \\
\text { assistance n (\%) }\end{array}$ & \\
\hline 1 & Self-awareness & 405(52.8) & 233(30.4) & $129(16.8)$ & $341(44.2)$ & 159(20.6) & $271(35.1)$ & $<0.0001$ \\
\hline 2 & Empathy & $352(46.5)$ & $263(37.7)$ & $142(18.8)$ & $359(46.7)$ & 150(19.5) & 260(33.8) & $<0.0001$ \\
\hline 3 & Coping with stress & $365(48.3)$ & $240(31.7)$ & $151(20.0)$ & $366(47.5)$ & 156(20.3) & $248(32.2)$ & $<0.0001$ \\
\hline 4 & Coping with emotions & $372(49.5)$ & $241(32.1)$ & 138(18.4) & $367(47.8)$ & 159(20.7) & $242(31.5)$ & $<0.0001$ \\
\hline 5 & Interpersonal skills & 373(49.8) & 232(31.0) & 144(19.2) & $359(46.6)$ & $162(21.0)$ & 249(32.3) & $<0.0001$ \\
\hline 6 & Critical thinking & $337(45.3)$ & 255(34.3) & 152(20.4) & $360(47.1)$ & $176(23.0)$ & 228(29.8) & $<0.0001$ \\
\hline 7 & Decision making & $352(46.9)$ & 247(32.9) & $151(20.1)$ & $337(44.1)$ & $164(21.5)$ & 263(34.4) & $<0.0001$ \\
\hline 8 & Problem solving & $331(44.3)$ & 264(35.3) & 152(20.3) & $359(47.0)$ & $157(20.5)$ & $248(32.5)$ & $<0.0001$ \\
\hline 9 & Communication skills & $340(45.3)$ & 239(31.8) & $172(22.9)$ & $309(40.1)$ & 178(23.1) & 283(36.8) & $<0.0001$ \\
\hline 10 & Creative thinking & $320(42.6)$ & $266(35.4)$ & $165(22.0)$ & $369(47.7)$ & 172(22.3) & $232(30.0)$ & $<0.0001$ \\
\hline
\end{tabular}


Table 4 Movement of participants between different categories of perceived level of confidence in teaching Life Skills (for each domain of life skills) after training

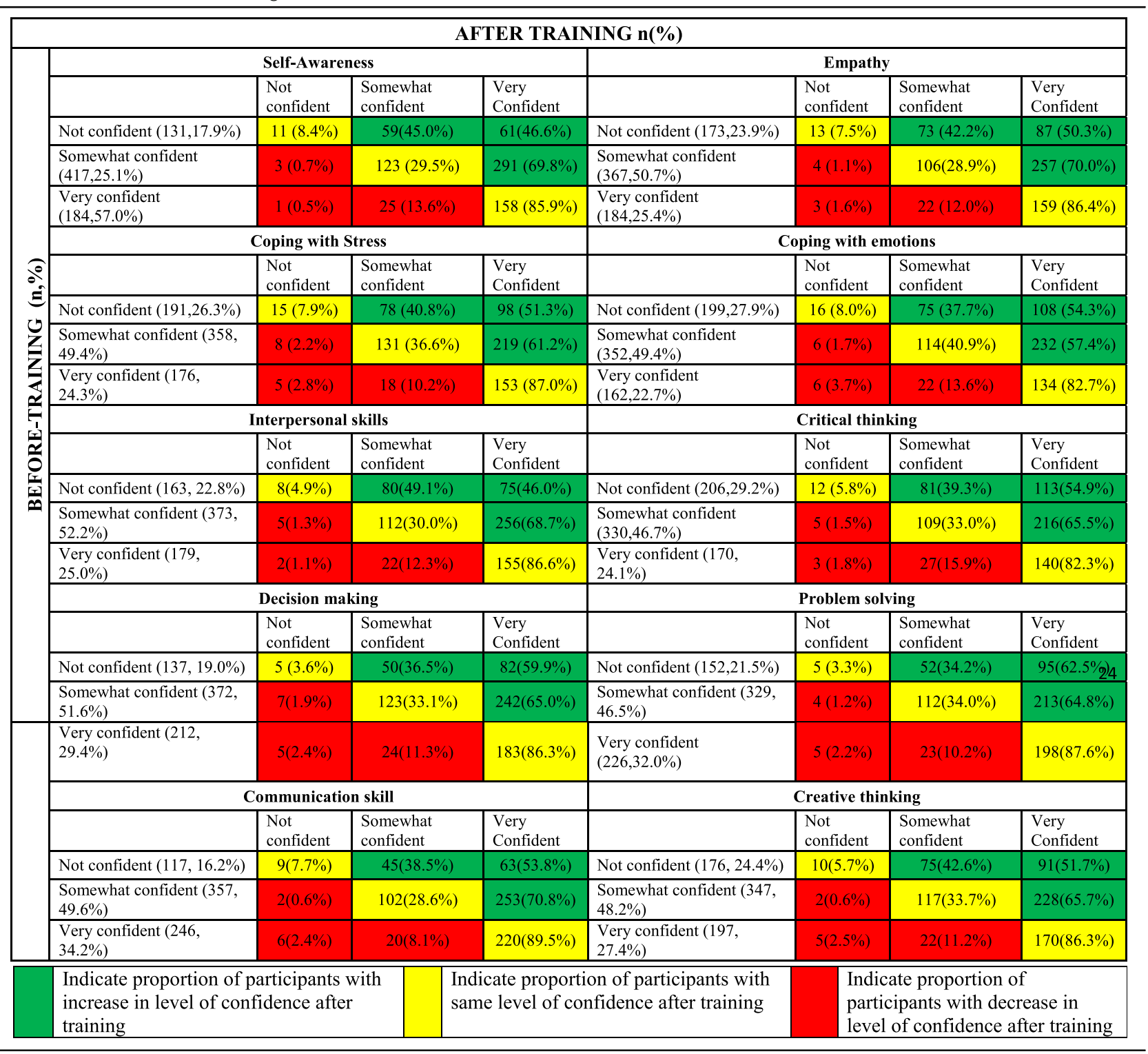

which ensured adequate support by government and educational institutions contributing to successful implementation of YLSECS program.

A systematic and objective assessment of the quality of YLSECS training program and its effect on participants knowledge and perception was undertaken and it was observed that nearly $90 \%$ of the participants rated the quality of training as either "Very Good" or "Excellent" (data not shown) which inturn is reflected in the domain mean scores (Fig. 1). Training has significantly improved participant's awareness about life-skills (level of awareness post training ranged between $91.5 \%$ for coping with emotion to $95 \%$ for communication skills) and increased their level of confidence in teaching life skills to students (percentage of participants reporting "very confident" ranged between $65 \%$ for coping with stress to $75 \%$ for communication skills post training). Considerable improvement in level of awareness was observed in the domains of coping with stress, coping with emotions and critical thinking. Interestingly, considerable proportion of participants who prior to training reported being confident in providing life skills training (without any assistance), later (i.e post training) reported they need some/more assistance for the same. It is likely that the participants, post training, would have possibly understood and got grounded about the nuances of life skills and more importantly the facilitatory role they need to play. 
Table 5 Movement of participants between different categories of perceived level of assistance needed in conducting Life Skills workshops (for each domain of life skills) after training

\begin{tabular}{|c|c|c|c|c|c|c|c|c|}
\hline \multicolumn{9}{|c|}{ AFTER TRAINING n(\%) } \\
\hline \multirow{25}{*}{ 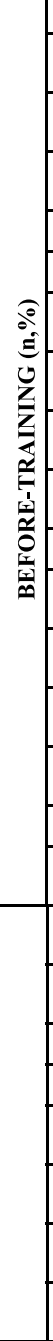 } & \multicolumn{4}{|c|}{ Self-Awareness } & \multicolumn{4}{|c|}{ Empathy } \\
\hline & & $\begin{array}{c}\text { More } \\
\text { assistance }\end{array}$ & $\begin{array}{c}\text { Little } \\
\text { assistance }\end{array}$ & $\begin{array}{c}\text { No } \\
\text { assistance }\end{array}$ & & $\begin{array}{c}\text { More } \\
\text { assistance }\end{array}$ & $\begin{array}{c}\text { Little } \\
\text { assistance }\end{array}$ & $\begin{array}{c}\text { No } \\
\text { assistance }\end{array}$ \\
\hline & $\begin{array}{l}\text { More assistance } \\
(220,30.2 \%)\end{array}$ & $56(25.5)$ & $114(51.8)$ & $50(22.7)$ & $\begin{array}{l}\text { More assistance } \\
(247,34.4 \%) \\
\end{array}$ & $49(19.8)$ & $142(57.5)$ & $56(22.7)$ \\
\hline & $\begin{array}{l}\text { Little assistance (386, } \\
53.0 \%)\end{array}$ & $69(17.9)$ & $170(44.0)$ & $147(38.1)$ & \begin{tabular}{|l|} 
Little assistance \\
$(337,46.9 \%)$
\end{tabular} & $60(17.8)$ & $159(47.2)$ & $118(35.0)$ \\
\hline & No assistance $(122,16.8 \%)$ & $21(17.2)$ & $40(32.8)$ & $61(50.0)$ & No assistance $(134,18.7 \%)$ & $29(21.6)$ & $36(26.9)$ & $66(50.0)$ \\
\hline & \multicolumn{4}{|c|}{ Coping with Stress } & \multicolumn{4}{|c|}{ Coping with emotions } \\
\hline & & $\begin{array}{c}\text { More } \\
\text { assistance }\end{array}$ & $\begin{array}{c}\text { Little } \\
\text { assistance }\end{array}$ & $\begin{array}{c}\text { No } \\
\text { assistance }\end{array}$ & & $\begin{array}{c}\text { More } \\
\text { assistance }\end{array}$ & $\begin{array}{c}\text { Little } \\
\text { assistance }\end{array}$ & $\begin{array}{c}\text { No } \\
\text { assistance }\end{array}$ \\
\hline & $\begin{array}{l}\text { More assistance } \\
(224,31.4 \%)\end{array}$ & $46(20.5)$ & $127(56.7)$ & $51(22.8)$ & $\begin{array}{l}\text { More assistance (227, } \\
31.9 \%)\end{array}$ & $49(21.6)$ & $128(56.4)$ & $50(22.0)$ \\
\hline & $\begin{array}{l}\text { Little assistance } \\
(344,48.2 \%)\end{array}$ & $65(18.9)$ & $163(47.4)$ & $116(33.7)$ & $\begin{array}{l}\text { Little assistance } \\
(350,49.2 \%)\end{array}$ & $64(18.3)$ & $180(51.4)$ & $106(30.3)$ \\
\hline & No assistance $(146,20.4 \%)$ & $35(24.0)$ & $45(30.8)$ & $66(45.2)$ & $\begin{array}{l}\text { No assistance (134, } \\
18.9 \%) \\
\end{array}$ & $31(23.1)$ & $36(26.9)$ & $67(50.0)$ \\
\hline & \multicolumn{4}{|c|}{ Interpersonal skills } & \multicolumn{4}{|c|}{ Critical thinking } \\
\hline & & $\begin{array}{c}\text { More } \\
\text { assistance }\end{array}$ & $\begin{array}{c}\text { Little } \\
\text { assistance }\end{array}$ & $\begin{array}{c}\text { No } \\
\text { assistance }\end{array}$ & & $\begin{array}{c}\text { More } \\
\text { assistance }\end{array}$ & $\begin{array}{c}\text { Little } \\
\text { assistance }\end{array}$ & $\begin{array}{c}\text { No } \\
\text { assistance }\end{array}$ \\
\hline & $\begin{array}{l}\text { More assistance } \\
(215,30.4 \%)\end{array}$ & $56(26.0)$ & $121(56.3)$ & $38(17.7)$ & $\begin{array}{l}\text { More assistance (237, } \\
34.0 \%)\end{array}$ & $53(22.4)$ & $137(57.8)$ & $47(19.8)$ \\
\hline & $\begin{array}{l}\text { Little assistance } \\
(355,50.2 \%)\end{array}$ & $64(18.0)$ & $168(47.3)$ & $123(34.6)$ & $\begin{array}{l}\text { Little assistance (314, } \\
45.0 \%)\end{array}$ & $64(20.4)$ & $152(48.4)$ & $98(31.2)$ \\
\hline & $\begin{array}{l}\text { No assistance (137, } \\
19.4 \%)\end{array}$ & $26(19.0)$ & $40(29.2)$ & $71(51.8)$ & No assistance $(147,21.0 \%)$ & $42(28.6)$ & $38(25.9)$ & $67(45.6)$ \\
\hline & \multicolumn{4}{|c|}{ Decision making } & \multicolumn{4}{|c|}{ Problem solving } \\
\hline & & $\begin{array}{c}\text { More } \\
\text { assistance }\end{array}$ & $\begin{array}{c}\text { Little } \\
\text { assistance }\end{array}$ & $\begin{array}{c}\text { No } \\
\text { assistance }\end{array}$ & & $\begin{array}{c}\text { More } \\
\text { assistance }\end{array}$ & $\begin{array}{c}\text { Little } \\
\text { assistance }\end{array}$ & $\begin{array}{c}\text { No } \\
\text { assistance }\end{array}$ \\
\hline & $\begin{array}{l}\text { More assistance (227, } \\
32.2 \%)\end{array}$ & $62(27.3)$ & $114(50.2)$ & $51(22.5)$ & \begin{tabular}{|l|} 
More assistance \\
$(248,35.4 \%)$
\end{tabular} & $67(27.0)$ & $130(52.4)$ & $51(20.6)$ \\
\hline & $\begin{array}{l}\text { Little assistance } \\
(332,47.0 \%)\end{array}$ & $62(18.7)$ & 159(47.9) & $111(33.4)$ & \begin{tabular}{|l|} 
Little assistance \\
$(308,43.9 \%)$ \\
\end{tabular} & $55(17.9)$ & $150(48.7)$ & $103(33.4)$ \\
\hline & No assistance $(147,20.8 \%)$ & $27(18.4)$ & $38(25.9)$ & $82(55.8)$ & No assistance $(145,20.7 \%)$ & $18(12.4)$ & $47(32.4)$ & $80(55.2)$ \\
\hline & \multicolumn{4}{|c|}{ Communication skill } & \multicolumn{4}{|c|}{ Creative thinking } \\
\hline & & $\begin{array}{c}\text { More } \\
\text { assistance }\end{array}$ & $\begin{array}{c}\text { Little } \\
\text { assistance }\end{array}$ & $\begin{array}{c}\text { No } \\
\text { assistance }\end{array}$ & & $\begin{array}{c}\text { More } \\
\text { assistance }\end{array}$ & $\begin{array}{c}\text { Little } \\
\text { assistance }\end{array}$ & $\begin{array}{c}\text { No } \\
\text { assistance }\end{array}$ \\
\hline & $\begin{array}{l}\text { More assistance } \\
(223,31.4 \%)\end{array}$ & $73(32.7)$ & $108(48.4)$ & $42(18.8)$ & \begin{tabular}{|l|} 
More assistance \\
$(252,35.4 \%)$
\end{tabular} & $73(29.0)$ & $129(51.2)$ & $50(19.8)$ \\
\hline & $\begin{array}{l}\text { Little assistance (323, } \\
45.6 \%)\end{array}$ & $58(18.0)$ & $142(44.0)$ & $123(38.1)$ & $\begin{array}{l}\text { Little assistance } \\
(303,42.6 \%) \\
\end{array}$ & $54(17.8)$ & $160(52.8)$ & $89(29.4)$ \\
\hline & $\begin{array}{l}\text { No assistance (163, } \\
23.0 \%)\end{array}$ & $27(16.6)$ & $39(23.9)$ & $97(59.5)$ & No assistance $(157,22.0 \%)$ & 29(18.5) & $49(31.2)$ & $79(50.3)$ \\
\hline & \multicolumn{2}{|c|}{$\begin{array}{l}\text { Indicate proportion of } \\
\text { participants needing less } \\
\text { assistance after training }\end{array}$} & & \multicolumn{2}{|c|}{$\begin{array}{l}\text { Indicate proportion of } \\
\text { participants with needing same } \\
\text { level of assistance after training }\end{array}$} & \multicolumn{3}{|c|}{$\begin{array}{l}\text { Indicate proportion of } \\
\text { participants needing more } \\
\text { assistance after training }\end{array}$} \\
\hline
\end{tabular}

The successful implementation of life skills education programme depends upon the provider confidence (one who imparts or conducts life skills training) and on the continued support and regular refresher training he/she (provider) receives $[13,15]$. Though considerable proportion of participants, in this study, expressed that they were confident in teaching life skills, only $30-37 \%$ of the participants, post training, perceived that they could independently conduct life skills training workshop without any (technical) assistance. This probably indicates that participants could be confident in teaching life skills in one-to-one basis, but not confident in conducting such training for large number of people in workshop mode. However, this is a natural process of learning and participants would feel confident in conducting life skills training workshop independently only upon implementing the training in their respective institutions and through the experience gained thereof. Furthermore, this describes the need for hand holding and supportive supervision for participants to conduct life skills training in their respective colleges. Therefore, as part of the program, following training, each participant is mandated to train 500 youth on life skills in their workplace. The YLSECS program team will provide hand-holding and supportive supervision to the teachers during their training workshops. 
Active participatory learning is central to imparting life skills [16] and is considered the basis for training of life skills trainers $[13,17,18]$. YLSECS training program was strongly grounded on facilitation cum participatory approach to training and was designed based on adult learning principles. This ensured active participation and learning by the participants which is probably reflected in the outcome of training. Furthermore, all the trainings were facilitated by experienced life skill training experts (psychologist, sociologist and others) who were well versed in training utilizing facilitation methods. Facilitation is known to provide experiential learning especially when learning from groups is required or when situation/question do not have a simple right answer and learning from others experience and ideas is required [19]. Life skills fit this criterion very well and hence the adoption of facilitation as a mode of imparting life skills to this group was envisaged.

Good quality training improves the professional skills and competencies needed for imparting life skills education among teachers $[15,20,21]$. Improving teacher's skills in this regard is of high priority in Life skills education programme being implemented in educational institutions [22]. The impact of skill based training is critically dependent on the facilitator (one who provides training) and most of the life skills education programme evaluation $[10,23,24]$ especially in which teachers are trained to impart life skills education to students, do not provide information on quality of the training and outcome among the teachers trained. The present study, conducted in a low resource setting, provides information to fill this critical knowledge gap.

Despite demonstrating significant improvement in knowledge, confidence and ability to conduct life skills training among the participants, present study has some limitations. Firstly, participants knowledge and perceived ability was assessed immediately after training and hence they do not reflect the sustained improvement in the outcome. However, there is an inbuilt evaluation planned under YLSECS program with a comparison group at three time points within a period of 1 year post training. Secondly, assessment of confidence and perceived ability to conduct life skills training was assessed using self administered questionnaire. It would have been ideal to assess such parameters by observing the participants while they are actually conducting life skills training. This is also being addressed as part of continued evaluation of YLSECS program by observing the teachers providing life skills training to their students or community in their own setting. Thirdly, we didn't assess the effect of facilitation as a mode of delivery, as this requires comparison with other methods of training (ex involving didactic method), due to resource constraints. However, feedback forms received from participants provides anecdotal evidence on the effectiveness of facilitation methods (data not shown). Finally, the participants being teachers were well educated with adequate teaching experience with many of them being NSS officers, they might have prior experience of life skills or maybe they are better implementers. Hence their understanding and acceptance about life skills would be better. The effect of such selection bias, if it exists, may not be ruled out in this study. Therefore, the results need testing if the training involves general population or other population groups.

\section{Conclusion}

To conclude, the YLSECS training program has significantly improved participant's knowledge and confidence about life skills and in implementing life skills training. However, there was modest increase in percentage of participants who perceived that they could implement life skills training without assistance. Based on the empirical evidence, it is strongly recommended that continued support and regular refresher training of teachers (or participants) who have undergone life skills training should be an essential component of life skills education programme. Furthermore, results of the study indirectly indicate the effectiveness of facilitating the process of learning among adult learners using active participatory approach and such or similar methods should be adopted for implementing life skills training among youth. The Karnataka state youth policy (2012) [25] and National Youth Policy of India (2014) [26] has identified life skills approach as one of the priority intervention for overall development of youth. Utilizing this opportunity, systems should be developed wherein resource persons/ facilities skilled in life skills training, could be networked and tasked with providing onsite and regular refresher training of NSS officers/teachers and continuously monitor and evaluate such trainings.

\section{Abbreviations \\ NIMHANS: National Institute of Mental health and Neuro Sciences; NSS: National Service Scheme; YLSECS: Youth focused Life Skills Educations and Counseling Services}

\section{Acknowledgements}

We would like to sincerely acknowledge the encouragement and support of former and present Director of NIMHANS. We are immensely thankful to the faculty, staff and students of Department of Epidemiology for their guidance and support. A special thanks to Yuva Spandana and YLSECS team, for their tireless effort in facilitating the training program. We wish to place on record our sincere gratitude to management of educational institutions from where the participants attended the training program. We also would like to thank the Departments of Pre-university education, Collegiate education, Technical education and Medical education for their cooperation. Most importantly we express our heartfelt thanks to participants for their active and enthusiastic participation and their family members for encouraging and supporting them. 


\section{Funding}

This work was supported by the Ministry of Youth Empowerment and Sports, Government of Karnataka, India [Government order No-52, Letter NoYESD/NSS/13/2015-16/251]. This funding source had no role in the design of this study, analyses, interpretation of the data, or decision to submit results.

\section{Availability of data and materials}

The datasets used and analyzed during the current study are available from the corresponding author on reasonable request.

\section{Authors' contributions}

$P B, A A B$ and $S R$ performed statistical analysis, drafted the first manuscript, revised all subsequent drafts, and approved the final manuscript. PB, GG and GSY designed the study, revised the first draft, and approved the final manuscript. SS, LG and MR has supervised the study, provided project guidelines, revised and critically reviewed all drafts of the manuscript, and approved the final manuscript.

\section{Ethics approval and consent to participate}

Ethics approval was obtained from the Institute Ethics Committee of NIMHANS (No NIMHANS/2nd IEC (BS \& NS DIV.)/2016). Written informed consent was obtained from participants prior to conducting the study.

\section{Consent for publication}

Not applicable.

\section{Competing interests}

The authors declare that they have no competing interests.

\section{Publisher's Note}

Springer Nature remains neutral with regard to jurisdictional claims in published maps and institutional affiliations.

\section{Author details}

'Department of Epidemiology, National Institute of Mental Health and Neurosciences, Bengaluru 560029, India. ${ }^{2}$ Administrative Medical Officer, Government Taluka Hospital, Gauribidanur 561208, India. ${ }^{3}$ Department of Youth Empowerment and Sports, Government of Karnataka, State Wing, National Services Scheme, Bengaluru 560029, India.

\section{Received: 21 January 2019 Accepted: 15 April 2019}

Published online: 02 May 2019

\section{References}

1. A Profile of adolescents and Youth in India. Ministry of Home Affairs, Government of India. New Delhi: Office of the Registrar General \& Census Commissioner.

2. Parasuraman S, Kishor S, Singh SK, Vaidehi Y. A Profile of Youth in India. National Family Health Survey (NFHS-3), India, 2005-06. Mumbai: International Institute for Population Sciences; 2009. Calverton, Maryland, USA: ICF Macro

3. International Institute for Population Sciences (IIPS) and Population Council. Youth in India: Situation and Needs 2006-2007. Mumbai: IIPS; 2010.

4. Chavan B, Das S, Garg R, Puri S, Banavaram AA. Prevalence of mental disorders in Punjab: Findings from National Mental Health Survey. Indian J Psychiatry. 2018;60(1):121-6. https://doi.org/10.4103/psychiatry. IndianJPsychiatry 221 17.

5. Gururaj G, Varghese M, Benegal V, Rao GN, Pathak K, Singh LK, et al. National Mental Health Survey of India, 2015-16: prevalence, patterns and outcomes. Bengaluru: National Institute of Mental Health and neuro sciences, NIMHANS Publication No 129; 2016.

6. India youth development index and report. Ministry of Youth Affairs and Sports, Government of India. Sriperumbudur: Rajiv Gandhi National Institute of Youth Development; 2017.

7. Youth in India. Ministry of Statistics and Programme Implementation, Government of India. New Delhi: Central Statistics Office; 2017.

8. Preparing the youth with the 21 st century skills needed to thrive in the knowledge economy. Misk Grand Challenges [Internet]. [cited 2018 Aug 18]. Available from: https://miskgrandchallenges.org/education_challenge.html.

9. Vranda MN, Rao MC. Life skills education for young adolescents-Indian experience. J Indian Acad Appl Psychol. 2011;37(9):9-15.
10. Global Evaluation of Life Skills Education Programmes. 2012. New York: United Nations Children's Fund.

11. Srikala B, Kumar KK. Empowering adolescents with life skills education in schools - school mental health program: does it work? Indian J Psychiatry. 2010;52(4):344.

12. National Service Scheme. Ministry of Youth Affairs and Sports, Government of India. [Internet]. [cited 2018 Oct 12]. Available from: https://nss.gov.in/nssdetail-page

13. Partners in life skills education - conclusions from a united nations interagency meeting. 1999. Geneva: Department of mental health, World Health Organisation [Internet]. [cited 2018 Jul 9]. Available from: http://www.who. int/mental_health/media/en/30.pdf

14. Kolb, DA. 2014. Experiential learning: experience as the source of learning and development. FT press.

15. World Health Organization information series on school health. Skills for health: skills-based health education including life skills-an important component of a child-friendly/health-promoting school [internet]. [cited 2018 Jul 9].Available from: http://www.who.int/school_youth_health/media/ en/sch_skills4health_03.pdf

16. Life skills education and CCE. New Delhi: Central Board of Secondary Education [Internet]. [cited 2018 Jul 9]. Available from: http://www.cbse.nic. in/cce/life_skills_cce.pdf

17. Life skills education for children and adolescents in school. World health Organization. Geneva: Programme on mental health; 1997.

18. Regional framework for introducing lifeskills education to promote the health of adolescents. 2001. New Delhi: WHO Regional Office for South-East Asia.

19. Desai M. Introduction to rights-based direct practice with children: Springer; 2018. 387 p

20. Kirby D, Kirby D. National Campaign to prevent teen and unplanned pregnancy (U.S.). Emerging answers, 2007: research findings on programs to reduce teen pregnancy and sexually transmitted diseases. Washington, DC: National Campaign to Prevent Teen and Unplanned Pregnancy; 2007.

21. Pillai R, Rajeev MMR, Parthasarathy R. Effectiveness of life skills education training for school teachers in a post disaster scenario. ARTHA J Soc Sci. 2013;13:41-51.

22. Kinsman J, Nakiyingi J, Kamali A, Carpenter L, Quigley M, Pool R, et al. Evaluation of a comprehensive school-based AIDS education programme in rural Masaka, Uganda. Health Educ Res. 2001;16(1):85-100.

23. Bikkrama Singh D, Menon R. Life skills in India an overview of evidence and current practices in our education system. New Delhi: Central Square Foundation; 2015

24. Life skills based education Programme in Pakistan an evaluation 2006-2010. Pakistan: world Population Foundation [internet]. [cited 2018 Jul 6]. Available from: https://hivhealthclearinghouse.unesco.org/library/ documents/life-skills-based-education-programme-pakistan-evaluation-20062010

25. Karnataka Youth Policy. 2012. Department of Youth Services and Sports, Government of Karnataka \& Karnataka Jnana Aayoga.

26. National Youth Policy. 2014. New Delhi: Ministry of Youth Affairs and Sports, Government of India.

Ready to submit your research? Choose BMC and benefit from:

- fast, convenient online submission

- thorough peer review by experienced researchers in your field

- rapid publication on acceptance

- support for research data, including large and complex data types

- gold Open Access which fosters wider collaboration and increased citations

- maximum visibility for your research: over $100 \mathrm{M}$ website views per year

At $\mathrm{BMC}$, research is always in progress.

Learn more biomedcentral.com/submission 